\title{
The use of news item video on YouTube to improve students' speaking ability at Grade XII of SMAN 2 Bandar Lampung
}

\author{
Annisa Azzahra ${ }^{1}$, Mahpul $^{2}$, Fajar Riyantika ${ }^{3}$ \\ Universitas Lampung, Jl. Prof. Dr. SumantriBrojonegoro, Rajabasa, Bandar Lampung ${ }^{1,2,3}$ \\ Correspondence: icanacin514@gmail.com
}

\begin{abstract}
In learning speaking, the students at Senior High School should be able to speak English appropriately. In the real condition, some students at Senior High School found difficulties in speaking English that is caused of some factors. One of the factors was how the teacher delivered the material. The materials were given by the teachers were not interesting. To make them interested and wanted to share their feelings in speaking English, the researcher used news item video as the media in the process of teaching and learning English. The research was intended to find out statistically significant improvement of the students' speaking ability after they got treatment by using news item video. The subjects of the research were 27 students at SMAN 2 Bandar Lampung. There were three raters who assessed students' speaking ability. The data were collected through speaking test (pretest and posttest). The paired simple t-test was used to analyze the data collected from both the pretest and posttest. The result showed that the news item video had statistically significant improvement on the students speaking ability with the significant level 0.05 . This suggest that the news item video facilitates students to improve their ability of speaking.
\end{abstract}

Keywords: Speaking, news item video, news item text, YouTube.

\section{INTRODUCTION}

This research aimed to find out the significant improvement of students' speaking ability after the students were taught by using news item. Speaking is a crucial part of second language learning and teaching (Kayi, 2006). In learning speaking, the students at Senior High School should be able to speak English appropriately. The students must be capable to build an interactive communication to express meaning in formal or informal conversation in the context of daily life. By being able to build an interactive communication, it means that the students can comprehend the conversation. Learning English as a foreign language is different thing to do for most Indonesian students, because it cannot be learnt naturally as they learn their first language. Usually learning foreign language means learning the dictionary, grammar and the sound of system in that language. Focusing on language form is important in foreign language learning but developing the ability to the real communication in English is the main goals of an English language course. At the end of a course, the learners should be able to communicate effectively in English in or outside the classroom for study, works or leisure.

In the real condition, some students of SMAN 2 Bandar Lampung find difficulties in speaking English. Based on the researcher's observation during PengenalanLingkunganPersekolahan (PLP) in SMAN 2 Bandar Lampung, the speaking inability of students are caused by several factors, those are: the lack of vocabulary mastery, the lack of self-confidence and the lack of ideas to speak. Students often have low self-confidence, and they are not pushed to express themselves in front the other students. When the teacher asks them to give personal information or opinion, most of them still take a long time to think the ideas on their mind. Students are often found themselves in trouble when they start to speak in English. They feel afraid of making mistakes and usually do not have enough bravery and motivation to learn and speak in English. Most of the students have not achieved the minimum standard criteria speaking based on genre, especially in news item. There are several problems why it can be happened such as, first, learning that often occurs in the class is still dominated by the teachers, so the learning carry out in the 
class is less effective. Second, there are still many teachers who think students as their loyal listener, hence the students cannot be active during the learning process.

Media can support students' interest to learn more about English and also media support teacher in teaching. The current study applies video to ease teachers and students during speaking learning process. The media that is used in this study is news item video. It is an authentic material in the form of audiovisual modality about a particular news which events of the day. The events are considered newsworthy or important it means if there is an important event that should be known by many people, then this event deserves news. Referring to the high school graduate standard, news item text should be completely studied in the first class with report text. According to Roswita (2018), to perform a report through news reporting the students were asked to develop a story or news in the form of writing in which later they should perform with their peers acting as news reporters. However, many students in senior high school do not yet achieve this ability to deliver the news in English well. Fortunately, news item is one of the lessons learned in senior high school. In news item, the students are taught how to comprehend the information in news. Students are required to be able to conceive information from the news since this ability is useful for the students themselves. In comprehending the news, students need to use their communication skills. They use their communication skill either to clarify the news or to give their opinion toward the news they are reading or listening to.

There are several studies have been conducted in the use of news video or YouTube videos especially for improving students' speaking skill. The first research was conducted by Lestari (2019), University of North Sumatra, Medan, this research was conducted to find out the improvement of the students' ability in writing News Item text by using Video. The result of the analysis data showed that mean of the pre-test was 64.3 and only 9 students $(31 \%)$ who got score 75 and passed the test. Based on the result of the students' responses in teaching learning process, the students were more active and felt interesting and enjoy at writing News Item text by using Video. The second research was conducted by Yunita (2015), Ganesha University of Education, she conducted a pre-experimental research about the effectiveness of using video YouTube toward students' speaking ability at the second grade of MTs PSM MirigambarTulungagung. The result shows that the mean score of students' speaking is 58.4375 before treatment was given and it becomes 67.8125 after the students were given treatment in which it means that there is a significant difference of students' speaking ability by using video YouTube. The third research was conducted by Aprilia (2019), Bina Dharma University, has done a research by using news videos to improve the speaking skill. Based on the result of the study, the writer concluded that news video was an effective medium to improve the students' speaking skill. The t-obtained, both in paired sample t-test and independent sample test, was higher than t-table. In other words, news video is effective to improve the students' speaking skill. The last research was conducted by Amalia (2011), Semarang States University, had done research improving students' ability in writing news item text by using old and new information. Based on the result of the data analysis, there was a significant difference average in students writing achievement. It was supported by the result of computation which showed significant difference between experimental and control group. Their writing was become more coherent than the student who got the treatment using jumbled sentences.

\section{METHODS}

The research design that the researcher would use in this study was a single group pretest-posttest design. Single group meant that this study used only in one class. Pretest-Posttest served to measure the success of the study. The researcher gave the pre-test to know students' speaking ability before the treatment and the post-test was used to find out the statistically significant improvement of students speaking ability after the implementation of guessing game technique. Referring to Setiyadi (2018), the design presents as follows:

$\mathbf{G}=\mathbf{T} 1 \mathbf{X} \mathbf{T} 2$ 
Where:

G: refers to the group (one class)

T1: refers the pre-test

$\mathrm{X}$ : means the treatment (the implementation of news item video)

T2: relates to the post-test

The researcher conducted the research by using one class. The subject of this research was one class the third grade students of SMA Negeri 2 Bandar Lampung that is XII MIPA 1 which consisted of 27 students. The instrument of this research was speaking test. The pre-test was administered to the students to measure their initial ability in speaking. The speaking test was based on the material in the syllabus. Post-test was administered to the students to know their achievement in speaking English through news item video applied in three treatments.

To get the reliability of the test, the researcher used inter-rater reliability. This inter-rater's reliability counted level of the reliability based on two series of score that were gotten by two raters or more simultaneously. The researcher asked two people who had the capability of assessing speaking to be the raters. The first rater was an English teacher of SMAN 2 Bandar Lampung, Ms. VrentiSiska, S.Pd., M.Pd. The second rater was Mr. Jonidam, S.Pd. where he was an English teacher in Youngster English Course. The reliability of these ability judgments could be determined by obtaining and comparing the scores of three raters. The scores of the raters could be correlated to determine the consistency of scoring. So, interrater reliability of the test was examined by using the Reliability Test in SPSS. In assessing the students' speaking test, the raters used the same scoring criteria. The criteria of scoring system are based on the following table:

Table 2.1 scoring table

\begin{tabular}{|lll|}
\hline Aspect of Speaking & $\begin{array}{c}\text { Rating } \\
\text { Scales }\end{array}$ & \multicolumn{1}{c|}{ Description } \\
\hline Pronunciation & $17-20$ & Speech is fluent and effortless as that native speaker. \\
\cline { 2 - 4 } $13-16$ & $\begin{array}{l}\text { Always intelligible though one is conscious of a } \\
\text { definite accent. }\end{array}$ \\
\cline { 2 - 4 } & $9-12$ & $\begin{array}{l}\text { Pronunciation problems necessitate concentrated } \\
\text { listening and occasionally lead to understanding. }\end{array}$ \\
\hline $5-8$ & $\begin{array}{l}\text { Very hard to understand because of pronunciation } \\
\text { problem most frequently be asked to repeat. }\end{array}$ \\
\hline $1-4$ & $\begin{array}{l}\text { Pronunciation problems so severe as to make speech } \\
\text { unintelligible. }\end{array}$ \\
\hline $17-20$ & $\begin{array}{l}\text { Use of vocabulary and idiom virtually that of a } \\
\text { native speaker. }\end{array}$ \\
\hline $13-16$ & $\begin{array}{l}\text { Sometimes use inappropriate terms and must } \\
\text { rephrase ideas, because of inadequate vocabulary. }\end{array}$ \\
\hline $9-12$ & $\begin{array}{l}\text { Frequently use the wrong word, conversation } \\
\text { somewhat limited because of inadequate vocabulary. }\end{array}$ \\
\hline $5-8$ & $\begin{array}{l}\text { Misuse of words and very limited vocabulary make } \\
\text { comprehension quite difficult. }\end{array}$ \\
\hline $1-4$ & $\begin{array}{l}\text { Vocabulary limitations are so extreme as to make } \\
\text { conversation virtually impossible. }\end{array}$ \\
\hline
\end{tabular}




\begin{tabular}{|c|c|c|}
\hline \multirow[t]{5}{*}{ Fluency } & $17-20$ & $\begin{array}{l}\text { Speech is fluent and effortless as that of a native } \\
\text { speaker. }\end{array}$ \\
\hline & $13-16$ & $\begin{array}{l}\text { Speed of speech seems rather strongly affected by } \\
\text { language problem }\end{array}$ \\
\hline & $9-12$ & $\begin{array}{l}\text { Make frequent errors of grammar or order, which } \\
\text { obscure meaning. }\end{array}$ \\
\hline & $5-8$ & $\begin{array}{l}\text { Usually, hesitant often forced into silence by the } \\
\text { language problems. }\end{array}$ \\
\hline & $1-4$ & $\begin{array}{l}\text { Speech is so halting and fragmentary as to make } \\
\text { conversation virtually impossible. }\end{array}$ \\
\hline \multirow[t]{5}{*}{ Comprehension } & $17-20$ & Appear to understand everything without difficulty. \\
\hline & $13-16$ & $\begin{array}{l}\text { Understand nearly everything at normal speed } \\
\text { although occasionally repetition may be necessary. }\end{array}$ \\
\hline & $9-12$ & $\begin{array}{l}\text { Understand most of what is said at slower normal } \\
\text { speed with repetition. }\end{array}$ \\
\hline & $5-8$ & Has great difficulty following what is said \\
\hline & $1-4$ & $\begin{array}{l}\text { It cannot be said to understand even simple } \\
\text { conversations in English. }\end{array}$ \\
\hline \multirow[t]{5}{*}{ Grammar } & $17-20$ & Grammar almost entirely inaccurate phrases. \\
\hline & $13-16$ & $\begin{array}{l}\text { Constant error control of very few major patterns } \\
\text { and frequently preventing communication. }\end{array}$ \\
\hline & $9-12$ & $\begin{array}{l}\text { Frequent errors showing some major patterns are } \\
\text { uncontrolled and causing occasional irritation and } \\
\text { misunderstanding. }\end{array}$ \\
\hline & $5-8$ & Few errors, with no patterns of failure. \\
\hline & $1-4$ & No more than two errors during the dialogue. \\
\hline
\end{tabular}

In collecting the data, some procedures were applied as follows:

1. Selecting and determining the population and sample

The population was all the twelfth-grade students in SMAN 2 Bandar Lampung. There were twelve classes, the researcher only took one class as the representative, and it was XII MIPA 1.

2. Finding and selecting the material

In this session, the materials were taken from YouTube. Furthermore, the news item was chosen as the material in this research. It was based on curriculum 2013 and school syllabus.

\section{Administering the pre-test}

Pre-test would be conducted before the treatments. This test was aimed at knowing the students' speaking ability before having the treatment. In this test, the students had to choose one of five news item texts then they had to deliver the text by delivering it in the form of videos that were uploaded to YouTube.

\section{Lesson plan trial}

Before doing treatment, the researcher conducted lesson plan trial to check whether the lesson plan made by the teacher is good or not. The researcher conducted lesson plan trial for three meetings with the students grade twelve at MA Diniyyah Putri Lampung. There are ten students from XII IPA 1 who joined lesson plan trial. The result from the lesson plan trial is the researcher need to revise some technical 
learning in learning activities, meanwhile the students could follow the learning material well. In conclusion, the researcher divided five aspects of speaking in learning material. There are comprehension and pronunciation in pre-activities, vocabulary and fluency in while activities, grammar in post-activities.

\section{Conducting treatment}

Treatment would be given in three meetings. For the first meeting, the students would watch video which consist of the explanation about news item in general along the example of how to deliver the news and the teacher would explain about news item material in general. The students' activities for the first meeting were asked by the teacher about the topic of the video that was given by the teacher. Then, the students found and identified the difficult words from the video and after that the teacher helped the students to pronounce the words clearly than the students repeated after the teacher. The students were given news item text by the teacher than the students read individually. After that, the teacher asked the students to read voluntarily. The teacher asked the students to find the difficult word that they do not know the meaning from the video. The teacher asked the students to find the synonym and antonym of the word that they found than they were asked to make sentences based on the tenses that was used in the video. Therefore, for the second and third meeting, the students would watch video about how to deliver the news with different topic and the students' activities were the same as the activities in the first meeting which was covered the five aspects of speaking.

\section{Administering the post test}

Post-test would be conducted after the treatments. This test was aimed to see the students' speaking ability after having the treatment by using news item video. In this test, the students would be given the same instruction as pre-test.

\section{Analyzing the data}

The result would be identified from the average scores of pre-tests and post-test compared to see the improvement of speaking achievement.

\section{RESULTS AND DISCUSSIONS}

The pre-test and post-test were administered in the experimental class to find out whether there is an improvement in students' speaking ability. Pre-test and post-test were given in the video project with time allocation was 3 minutes in each video. The pre-test was conducted in order to know the students' speaking ability before being given treatments. The mean score of pre-tests was 61.5. The highest score was 74 and the lowest score was 54 . The frequency of the pre-test was listed as follows:

Table 3.1 distribution frequency of students' pre-test score of speaking

\begin{tabular}{|c|c|c|c|c|c|}
\hline & & Frequency & Percent & Valid Percent & $\begin{array}{c}\text { Cumulative } \\
\text { Percent }\end{array}$ \\
\hline \multirow{8}{*}{ Valid } & 54.00 & 1 & 3.7 & 3.7 & 3.7 \\
\hline & 55.00 & 1 & 3.7 & 3.7 & 7.4 \\
\hline & 57.00 & 3 & 11.1 & 11.1 & 18.5 \\
\hline & 58.00 & 4 & 14.8 & 14.8 & 33.3 \\
\hline & 59.00 & 1 & 3.7 & 3.7 & 37.0 \\
\hline & 60.00 & 3 & 11.1 & 11.1 & 48.1 \\
\hline & 61.00 & 6 & 22.2 & 22.2 & 70.4 \\
\hline & 62.00 & 1 & 3.7 & 3.7 & 74.1 \\
\hline
\end{tabular}




\begin{tabular}{rrrrr|}
\hline 64.00 & 1 & 3.7 & 3.7 & 77.8 \\
67.00 & 2 & 7.4 & 7.4 & 85.2 \\
68.00 & 1 & 3.7 & 3.7 & 88.9 \\
71.00 & 1 & 3.7 & 3.7 & 92.6 \\
73.00 & 1 & 3.7 & 3.7 & 96.3 \\
74.00 & 1 & 3.7 & 3.7 & 100.0 \\
Total & 27 & 100.0 & 100.0 & \\
\hline
\end{tabular}

Meanwhile, the post-test was administered in order to determine whether there was a significant improvement of the students' speaking ability or not after giving three treatments. The students were asked to make a video project as like pre-test, but the text for post-test has been paraphrased before. The mean score of post-tests was 68.7. The highest score was 82 and the lowest score was 60. The researcher used Statistical Computation with SPSS 20 for Windows to analyze the scores on the post-test of students' speaking ability. The distribution score of the post-test of students' speaking ability is explained in the following table:

Table 3.2 distribution frequency of students' post-test score of speaking

\begin{tabular}{|r|r|r|r|r|}
\hline & Frequency & Percent & Valid Percent & $\begin{array}{c}\text { Cumulative } \\
\text { Percent }\end{array}$ \\
\hline 60.00 & 1 & 3.7 & 3.7 & 3.7 \\
61.00 & 1 & 3.7 & 3.7 & 7.4 \\
62.00 & 2 & 7.4 & 7.4 & 14.8 \\
63.00 & 2 & 7.4 & 7.4 & 22.2 \\
64.00 & 1 & 3.7 & 3.7 & 25.9 \\
65.00 & 2 & 7.4 & 7.4 & 33.3 \\
66.00 & 3 & 11.1 & 11.1 & 44.4 \\
67.00 & 2 & 7.4 & 7.4 & 51.9 \\
69.00 & 1 & 3.7 & 3.7 & 55.6 \\
70.00 & 2 & 7.4 & 7.4 & 63.0 \\
71.00 & 2 & 7.4 & 7.4 & 70.4 \\
72.00 & 2 & 7.4 & 7.4 & 77.8 \\
73.00 & 1 & 3.7 & 3.7 & 81.5 \\
75.00 & 1 & 3.7 & 3.7 & 85.2 \\
76.00 & 1 & 3.7 & 3.7 & 88.9 \\
77.00 & 1 & 3.7 & 3.7 & 92.6 \\
80.00 & 1 & 3.7 & 3.7 & 96.3 \\
82.00 & 1 & 3.7 & 3.7 & 100.0 \\
Total & 27 & 100.0 & 100.0 & \\
\hline
\end{tabular}

The normality test was used to measure whether the data of the test had normal distribution or not. The researcher used One Sample Kolmogorov-Smirnov Test with SPSS 20.0 for Windows. The Result of the normality test can be seen in the table below:

Table 3.3 result of normality test

\begin{tabular}{|lrrr|}
\hline & & Pretest & \multicolumn{1}{c|}{ Postest } \\
\hline N & 27 & 27 \\
Normal Parameters & & & \\
& Mean & 61.59 & 68.70
\end{tabular}




\begin{tabular}{|llrr|} 
& Std. Deviation & 5.228 & 5.843 \\
& Absolute & .249 & .133 \\
Most Extreme Differences & Positive & .249 & .133 \\
& Negative & -.116 & -.068 \\
Kolmogorov-Smirnov Z & & 1.293 & .692 \\
Asymp. Sig. (2-tailed) & & .071 & .724 \\
\hline
\end{tabular}

a. Test distribution is Normal.

b. Calculated from data.

The pre-test and post-test scores were normally distributed because the sig ( 2 tailed) was higher than 0.05. In brief, it could be assumed that the scores in pre-test and post-test had normal distribution.

Comparing result of the pre-test and post-test from this research in which the mean score of pre-tests was 61.5 and the mean score of the post-test was 68.7. It could be seen that the mean of the students' score on pre-test and post-test were significantly different, it increased from 61.5 to 68.7. There was difference for about 7.2 point after being given the treatments. Besides that, there were significant improvement in every aspect of speaking too. It could be seen in the tables and explanation below:

Table 3.4 the comparison between pretest and posttest score in every aspect speaking

\begin{tabular}{|c|c|c|c|c|c|c|c|c|c|c|c|}
\hline \multirow{2}{*}{ No } & \multirow{2}{*}{ Name } & \multicolumn{2}{|c|}{ Pronunciation } & \multicolumn{2}{|c|}{ Vocabulary } & \multicolumn{2}{|c|}{ Fluency } & \multicolumn{2}{|c|}{ Comprehension } & \multicolumn{2}{|c|}{ Grammar } \\
\hline & & Pre & Post & Pre & Post & Pre & Post & Pre & Post & Pre & Post \\
\hline 1. & S1 & 16 & 16 & 15 & 16 & 13 & 16 & 14 & 16 & 14 & 16 \\
\hline 2. & S2 & 11 & 13 & 10 & 12 & 12 & 12 & 12 & 13 & 11 & 11 \\
\hline 3. & S3 & 13 & 13 & 14 & 16 & 12 & 15 & 13 & 14 & 15 & 16 \\
\hline 4. & S4 & 12 & 12 & 12 & 13 & 11 & 13 & 11 & 13 & 15 & 15 \\
\hline 5. & S5 & 13 & 15 & 12 & 13 & 12 & 13 & 12 & 14 & 14 & 15 \\
\hline 6. & S6 & 14 & 15 & 14 & 15 & 12 & 15 & 14 & 16 & 15 & 15 \\
\hline 7. & S7 & 13 & 14 & 13 & 13 & 11 & 13 & 12 & 12 & 12 & 12 \\
\hline 8. & S8 & 11 & 11 & 12 & 12 & 11 & 11 & 11 & 13 & 11 & 14 \\
\hline 9. & S9 & 12 & 14 & 13 & 14 & 11 & 14 & 13 & 12 & 11 & 13 \\
\hline 10 & S10 & 12 & 13 & 12 & 13 & 11 & 13 & 13 & 13 & 12 & 13 \\
\hline 11 & S11 & 12 & 13 & 12 & 14 & 11 & 12 & 12 & 13 & 12 & 15 \\
\hline 12 & S12 & 11 & 13 & 11 & 13 & 11 & 12 & 13 & 12 & 11 & 13 \\
\hline 13 & S13 & 12 & 13 & 12 & 13 & 12 & 12 & 12 & 14 & 11 & 13 \\
\hline 14 & S14 & 13 & 14 & 12 & 13 & 12 & 13 & 12 & 13 & 12 & 12 \\
\hline 15 & S15 & 12 & 14 & 11 & 15 & 12 & 13 & 13 & 14 & 13 & 14 \\
\hline 16 & S16 & 13 & 15 & 12 & 13 & 11 & 12 & 12 & 13 & 11 & 14 \\
\hline 17 & S17 & 13 & 14 & 14 & 14 & 12 & 14 & 13 & 14 & 12 & 14 \\
\hline 18 & S18 & 12 & 12 & 13 & 12 & 11 & 12 & 12 & 12 & 13 & 14 \\
\hline 19 & S19 & 11 & 11 & 12 & 12 & 12 & 13 & 11 & 14 & 11 & 13 \\
\hline 20 & S20 & 12 & 15 & 11 & 15 & 11 & 13 & 11 & 15 & 13 & 14 \\
\hline 21 & S21 & 12 & 12 & 12 & 12 & 12 & 12 & 12 & 13 & 11 & 13 \\
\hline 22 & S22 & 14 & 15 & 13 & 16 & 13 & 15 & 13 & 15 & 14 & 16 \\
\hline 23 & S23 & 13 & 14 & 12 & 14 & 12 & 14 & 12 & 15 & 12 & 14 \\
\hline 24 & S24 & 11 & 14 & 14 & 14 & 12 & 14 & 12 & 13 & 11 & 13 \\
\hline 25 & S25 & 15 & 16 & 14 & 15 & 12 & 15 & 14 & 15 & 12 & 16 \\
\hline 26 & S26 & 12 & 13 & 12 & 14 & 13 & 15 & 11 & 15 & 12 & 15 \\
\hline 27 & S27 & 15 & 17 & 15 & 17 & 15 & 16 & 15 & 16 & 14 & 17 \\
\hline Tot & average & 12 & 14 & 12 & 14 & 12 & 13 & 12 & 14 & 12 & 14 \\
\hline
\end{tabular}


It could be seen from the table above, the mean of pre-test and post-test in every single aspect of speaking was different. The post-test score had higher score than pre-test score. In other words, there was significant improvement in every aspect of students' speaking ability after taught by using news item video.

\section{Discussions}

Based on the result of this research, the students' speaking ability improved after being taught by news item video at the third grade of SMAN 2 Bandar Lampung. In other words, news item video can be used to make a significant improvement in the students' speaking ability. The significant improvement can be seen by comparing the mean score between the pre-test and post-test.

In the pre-test, the research found out many students did not know how to deliver the news well. It can be seen from the students' video project which most of them did not use opening and closing in delivering the news. Researcher also still found the problem in their aspects of speaking like; how to pronounce the word, lack of vocabulary for opening and closing, the fluency of delivering the news, their comprehension in understanding the news and also the grammar of composing the news item text. As the result, they did not perform well. After conducting the research, there were some advantages from news item video; it can be used as information for English teachers, especially in teaching speaking through news item video, and to know the significant improvement of the students' speaking ability after the treatments. Besides that, there were also disadvantages that found in this research. Not all the students have a good performance in making video project. It might be caused some students felt not confident to speak and also the lack of strategy to raise their attention. It needs more arrangement to make the learning process run well. So, it means that improvement is needed as a reference for the next research.

From the result of this research, the researcher found that the students who were taught by using news item video could achieve a better result in learning English speaking. The research had proved that news item video could make the students be more active, innovative and creative in the learning process. It is supported by Roswita (2018) who stated that performing a report through news reporting, the students were asked to develop news in the form of writing in which later they should perform with their peers acting as news reporting. So, the students can have their own creative video as like a newscaster for example in making opening and closing for delivering the news. Meanwhile, according to Aprilia (2019) news video was an effective medium to improve the students' speaking skill. Therefore, news item video is a media that was used in the treatment for this research. It can be inferred that the problem students faced in speaking can be minimalized after they got the treatments. Therefore, the students' ability in speaking had been improved.

\section{CONCLUSIONS}

The purpose of this research is to find out whether there is an improvement in students' speaking ability after the implementation by using news item video. Based on the research, it is concluded that the implementation of news item video was effective to improve students' speaking ability. Based on the result of the test and analyzing the data, there was an improvement in students' speaking ability after the implementation of news item video in SMAN 2 Bandar Lampung. It could be seen from the improvements of students' speaking ability in the pre-test and post-test. The mean score improved from 61.5 in pre-test to 68.7 in post-test. The result of the hypothesis test showed that there was a significant improvement after being taught by using news item video, the value of sig ( 2 tailed) is lower than 0.05 $(0.000<0.05)$. 


\section{REFERENCES}

Amalia, R. (2011). Improving students' ability in writing news item text by using old and new information. Semarang: Universitas Negeri Semarang.

Aprilia, F. (2019). Using news video to improve the speaking skill of EFL students in Palembang. Palembang: Bina Dharma University

Kayi, H. (2006). Teaching speaking: Activities to promote speaking in a second language.The Internet TESL Journal, 12(11), 1-6.

Lestari, A. (2019). Improving the students' achievement in writing news item text by using video at Madrasah Aliyah Al-ManaarAsahan (Doctoral dissertation, Universitas Islam Negeri Sumatera Utara).

Roswita, A. (2018). Enhancing the students speaking interest through news reporting technique. Asian EFL Journal, 70-78.

Setiyadi, B. (2018) Metode penelitianuntuk pengajaran Bahasa Asing. Yogyakarta: GrahaIlmu

Yunita, L. S. (2015). The effectiveness of using video Youtube toward students' speaking ability at the second grade of MTS PSM Mirigambar, Tulungagung. Tulungagung: IAIN of Tulungagung. 